\title{
Negative anti-neutrophil cytoplasmic antibodies and eosinophilic granulomatosis with polyangiitis accompanied by cough variant asthma: a case report
}

\author{
Yanming $\mathrm{Li}^{1 \#}$, Zhengli Chen ${ }^{1 \#}$, Shumin $\mathrm{Zhu}^{1}$, Fan Bai ${ }^{1}$, Yuecai Liu ${ }^{1}$, Lingling Gao ${ }^{2}$, Xinyuan $\mathrm{Li}^{1}$, \\ Yulan Geng', Guoqiang Zhang ${ }^{3}$ \\ ${ }^{1}$ Department of Laboratory Medicine, The First Hospital of Hebei Medical University, Shijiazhuang, China; ${ }^{2}$ Physical Examination Center, The \\ First Hospital of Hebei Medical University, Shijiazhuang, China; ${ }^{3}$ Department of Dermatology, The First Hospital of Hebei Medical University, \\ Shijiazhuang, China \\ \#These authors contributed equally to this work. \\ Correspondence to: Yulan Geng, MD. Department of Laboratory Medicine, The First Hospital of Hebei Medical University, 89 Donggang Road, \\ Shijiazhuang 050031, China. Email: ylgeng123@163.com; Guoqiang Zhang, PhD, MD. Department of Dermatology, The First Hospital of Hebei \\ Medical University, 89 Donggang Road, Shijiazhuang 050031, China. Email: zlx090702@163.com.
}

\begin{abstract}
Eosinophilic granulomatosis with polyangiitis (EGPA), formerly called Churg-Strauss syndrome, is a rare chronic necrotizing eosinophilic granulomatous inflammatory disease characterized by eosinophil-rich granulomatous inflammation and small- to medium-size vessel vasculitis associated with bronchial asthma and eosinophilia, which is positive for anti-neutrophil cytoplasmic antibody (ANCA) in approximately $50-70 \%$ of cases. We report a case of a 23 -year-old woman was admitted to our hospital because of a of small vesicles on both lower limbs and a 4-month history of small scattered skin rash with pruritus V6 on both lower limbs four-month history of scattered skin rash with pruritus. Laboratory data from peripheral blood revealed leukocytosis, eosinophilia, thrombocytosis, hyperfibrinolysis, and mild renal injury. Her ANCA was negative, and the skin pathological examination showed granuloma lesions with eosinophils, while elevated eosinophils were also found in the bone marrow. EGPA was diagnosed. On the other hand, the patient had 2-year-long rhinosinusitis, 9-month-long nephrotic syndrome, and 1-month-long dry cough, which might be a type of asthma. With steroid therapy followed by systemic immunomodulatory therapy, the patient's symptoms were relieved. Our case report and literature review highlight the importance of recognizing cough variant asthma as an initial presenting symptom of EGPA, providing an opportunity for early diagnosis and treatment to reduce the risk of further disease progression and morbidity.
\end{abstract}

Keywords: Eosinophilic granulomatosis with polyangiitis (EGPA); cough variant asthma; anti-neutrophil cytoplasm antibody (ANCA); case report; herpes simplex virus (HSV)

Submitted Jun 18, 2021. Accepted for publication Sep 28, 2021.

doi: 10.21037/apm-21-2236

View this article at: https://dx.doi.org/10.21037/apm-21-2236

\section{Introduction}

According to the 2012 Chapel Hill Consensus Conference, eosinophilic granulomatosis with polyangiitis (EGPA), also known as Churg-Strauss syndrome, is defined as eosinophilrich necrotizing vasculitis and extravascular granuloma formation of small-to-medium size blood vessels (1). However, the exact pathogenesis is still unknown. It is generally agreed that EGPA is an anti-neutrophil cytoplasmic antibody (ANCA)-associated vasculitis (AAV), which is positive for ANCA in approximately $50-70 \%$ of cases $(2,3)$, especially in patients with glomerulonephritis (4). The time from disease activity to diagnosis was shorter in ANCA positive patients than in ANCA negative patients, and the inflammatory response was more severe. EGPA 
is associated with asthma, eosinophilia, allergic rhinitis, eosinophil-rich vasculitis, polyneuropathy, purpura, gastrointestinal ulcer, cerebral infarction, and myocardial infarction (5). Cough variant asthma refers to chronic cough as the only or the main clinical manifestations of a special type of asthma, is the first cause of chronic cough in adults. Therefore, EGPA is difficult to diagnose due to the diversity of its manifestations. Up to now, the diagnosis is still based on classification criteria proposed by the American College of Rheumatology in 1990 (6).

Here, we describe a case of EGPA that presented with cough variant asthma and negative ANCA. A literature review of similar cases was completed and is summarized. We present the following article in accordance with the CARE reporting checklist (available at https://dx.doi. org/10.21037/apm-21-2236).

\section{Case presentation}

A 23-year-old Chinese female with a history of 4-month purplish red itching rash all over the body without any clear causes was admitted to the rheumatology department of our hospital. She took part in the routine vaccination schedule, as she was growing up. She did not report any history of surgical operations or injury or allergies to foods or medicines. She had a history of nephrotic syndrome for 9 months, and chronic rhinosinusitis for the last 2 years. She was medically maintained by another hospital on ciclosporin, methylprednisolone acetate, and leflunomide. Rashes, itching, and edema of the face, double eyelids, and two lower limbs had appeared 4 months previously. One month ago, she reported more serious itching rashes, including an increasing number of vesicles on both lower extremities, with a dry cough. Recently there was no noticeable improvement of her condition, even though she had been taking medicines continuously.

Physical examination on admission revealed scattered red rashes all over her skin and vesicles on her two lower limbs. Her blood pressure was $89 / 67 \mathrm{mmHg}$, her pulse rate was $134 / \mathrm{min}$, and her body temperature was $37.0^{\circ} \mathrm{C}$. She had a dry cough. The patient did not have a swollen throat or tonsils. Her respiratory sounds were normal, and no heart murmur was heard. Her abdomen was soft, without tenderness or rebound tenderness, and her liver and spleen were impalpable. Her muscle response was normal. No joint swelling and pain were present. However, she had mild pitting edema in both extremities. The neurological findings did not reveal any obvious sensory or movement disorder.

On admission, the laboratory findings revealed an elevated white blood cell count $\left(14.10 \times 10^{9} / \mathrm{L}\right)$ and neutrophil count $\left(9.10 \times 10^{9} / \mathrm{L}\right)$, an elevated eosinophil proportion $(18.5 \%)$ and count $\left(2.60 \times 10^{9} / \mathrm{L}\right)$, an elevated platelet (Plt) count $\left(505 \times 10^{9} / \mathrm{L}\right)$, and there were no atypical lymphocytes. The erythrocyte sedimentation rate (ESR) was normal $(1 \mathrm{~mm} / \mathrm{h})$. Her serum lactate dehydrogenase $(\mathrm{LDH})(548.0 \mathrm{U} / \mathrm{L})$, creatine kinase (CK) (234.0 U/L), CK-MB (165.0 U/L), and C-reactive protein (CRP) $(15.39 \mathrm{mg} / \mathrm{L})$ were increased, while the serum total protein (TP) $(56.9 \mathrm{~g} / \mathrm{L})$ and albumin (Alb) $(31.8 \mathrm{~g} / \mathrm{L})$ were decreased.

In addition, her plasma D-dimer (DD) $(2.87 \mathrm{mg} / \mathrm{L})$ and fibrin(ogen) degradation product (FgDP) $(5.22 \mathrm{mg} / \mathrm{L})$ were higher, while her activated partial thromboplastin time (aPTT) was $27.4 \mathrm{~s}$ close to the lower reference limit. The lupus anticoagulant ratio (1.09) was within reference limits. Positive serum anti-herpes simplex virus (HSV) type $1+2$ immunoglobulin (IgG) and anti-rubella virus (RV) IgG were 14.46 and $15.10 \mathrm{AU} / \mathrm{mL}$, respectively. Various autoantibodies including ANCA were negative.

Peripheral blood lymphocyte subsets with Flow Cytometer (Beckman Coulter Navios, Sydney, Australia) showed elevated $\mathrm{T}$ cells, $\mathrm{CD} 4^{+} \mathrm{T}$ cells, an elevated $\mathrm{CD} 4^{+}$ $\mathrm{T} / \mathrm{CD}^{+} \mathrm{T}$ ratio, a lower $\mathrm{CD} 8^{+} \mathrm{T}$ cells count, decreased $B$ cells, decreased natural killer (NK) cells and decreased natural killer-like T cells (NKT) in terms of both percentage and count. The $\mathrm{CD}^{+} \mathrm{T}$ count was close to the low reference limit. Her regulatory T cells (Treg) was within the reference range. Peripheral cytokines showed elevated interleukin (IL)-6, IL-10, and interferon $\gamma(\gamma$-IFN), and decreased tumor necrosis factor $\alpha(\mathrm{TNF}-\alpha)$. Serum complement tests showed decreased complement 1q (C1q) and complement 3 (C3) (See Table 1).

On admission, bone marrow cytomorphology revealed three cell line proliferation and elevated eosinophils (see Figure 1). Her skin biopsy specimens also showed a lot of eosinophils (see Figure 2).

Computed tomography (CT) scans showed: bilateral ethmoid sinusitis at admission, multiple small patchy and high-density nodules in the lungs (see Figure 3), multiple small lymph node enlargement in the mediastinum and bilateral axillary fossa, and some pericardial effusion.

Based on findings of eosinophil-infiltrating granulomatous vasculitis of the skin accompanied by notable peripheral blood eosinophilia, sinusitis, intractable cough, and pulmonary nodules on radiographic evaluation, she met the American College of Rheumatology criteria (6) 
Table 1 Laboratory findings on admission

\begin{tabular}{|c|c|}
\hline Project & Results \\
\hline \multicolumn{2}{|l|}{ Lymphocyte subsets } \\
\hline T\% & $89.60 \%$ \\
\hline $\mathrm{CD} 4^{+} \mathrm{T} \%$ & $56.93 \%$ \\
\hline $\mathrm{CD}^{+} \mathrm{T} \%$ & $27.13 \%$ \\
\hline CD4/CD8 & 2.10 \\
\hline $\mathrm{B} \%$ & $5.97 \%$ \\
\hline NK\% & $2.37 \%$ \\
\hline NKT\% & $2.13 \%$ \\
\hline Regulatory T cell (Treg) \% & $2.25 \%$ \\
\hline $\mathrm{T}$ count & 1,523 cells $/ \mu \mathrm{L}$ \\
\hline $\mathrm{CD} 4^{+}$count & 968 cells $/ \mu \mathrm{L}$ \\
\hline $\mathrm{CD}^{+} \mathrm{T}$ count & 461 cells $/ \mu \mathrm{L}$ \\
\hline B count & 101 cells/ $\mu \mathrm{L}$ \\
\hline NK count & 40 cells $/ \mu \mathrm{L}$ \\
\hline NKT count & 36 cells/ $\mu \mathrm{L}$ \\
\hline Treg count & 38 cells $/ \mu \mathrm{L}$ \\
\hline \multicolumn{2}{|l|}{ Plasma cytokines } \\
\hline IL-2 & $1.96 \mathrm{pg} / \mathrm{mL}$ \\
\hline IL-4 & $2.03 \mathrm{pg} / \mathrm{mL}$ \\
\hline II-6 & $15.26 \mathrm{pg} / \mathrm{mL}$ \\
\hline IL-10 & $12.93 \mathrm{pg} / \mathrm{mL}$ \\
\hline IL-17A & $1.41 \mathrm{pg} / \mathrm{mL}$ \\
\hline IFN- $\gamma$ & $2.17 \mathrm{pg} / \mathrm{mL}$ \\
\hline TNF- $\alpha$ & $1.12 \mathrm{pg} / \mathrm{mL}$ \\
\hline \multicolumn{2}{|c|}{ Serum immunoglobulin and complements } \\
\hline $\lg A$ & $2.32 \mathrm{~g} / \mathrm{L}$ \\
\hline $\lg G$ & $9.94 \mathrm{~g} / \mathrm{L}$ \\
\hline $\lg M$ & $0.86 \mathrm{~g} / \mathrm{L}$ \\
\hline Factor B & $221.2 \mathrm{~g} / \mathrm{L}$ \\
\hline $\mathrm{C} 1 \mathrm{q}$ & $118 \mathrm{mg} / \mathrm{L}$ \\
\hline $\mathrm{C} 3$ & $0.80 \mathrm{~g} / \mathrm{L}$ \\
\hline $\mathrm{C} 4$ & $0.13 \mathrm{~g} / \mathrm{L}$ \\
\hline
\end{tabular}

T, T lymphocyte; B, B lymphocyte; NK, natural killer; NKT, NKlike T cell; Treg, regulatory T lymphocyte; IL, interleukin; IFN- $\gamma$, interferon $\gamma$; TNF- $\alpha$, tumor necrosis factor $\alpha$; Ig, immunoglobulin; $\mathrm{C}$, complement. for EGPA. She was diagnosed with EGPA with cough variant asthma. With steroid therapy (methylprednisolone sodium succinate, $40 \mathrm{mg}$, ivgtt, ONCE) followed by systemic immunomodulatory therapy, the patient's peripheral blood eosinophil proportion and count from the first $18.5 \%$ $\left(2.60 \times 10^{9} / \mathrm{L}\right)$ to $33.9 \%\left(9.30 \times 10^{9} / \mathrm{L}\right), 24.3 \%\left(3.87 \times 10^{9} / \mathrm{L}\right)$, $0.8 \%\left(0.08 \times 10^{9} / \mathrm{L}\right)$ one week interval, her symptoms obviously improved, although her asthma was improved only slightly. One month later, she was discharged with a prescription of a regular steroid and cyclosporine A.

All procedures performed in studies involving human participants were in accordance with the ethical standards of the institutional and/or national research committee(s) and with the Helsinki Declaration (as revised in 2013). Written informed consent was obtained from the patient for publication of this case report and accompanying images. A copy of the written consent is available for review by the editorial office of this journal.

\section{Discussion}

Our patient had a cough variant asthma phenotype with peripheral eosinophilia and elevated eosinophils in bone marrow besides eosinophil-infiltrated skin lesions, and she also had a history of nephrotic syndrome for 9 months and chronic rhinosinusitis for 2 years.

The patient was a 23 -year-old woman. Patients have typical age demographics for this disease, with few cases occurring during childhood and in those over 70 years (7). We also noticed that female adults are more likely to get EGPA based on case reports published in recent years (8-14), while about $38 \%$ of children with EGPA are female (15).

Some studies suggest that cutaneous manifestations are present in $40 \%$ to $81 \%$ of EGPA patients (16). It has been reported that the most common presenting features of EGPA in children are: pulmonary (69\%), skin (61-64\%), gastrointestinal (46\%), and cardiac manifestations (46\%); paranasal sinus abnormality (38\%); arthritis/arthralgia (38\%); neurological involvement (15\%); and even vasculitis $(15,17-19)$. In another study of children, the respiratory system was found to be mostly involved, mainly the upper airways (85\%), while other frequently involved organ systems were the skin $(71 \%)$, digestive tract $(64 \%)$, and heart (57\%) (20).

However, regardless of whether children or adult patients are affected, some manifestations are rare, with some case 

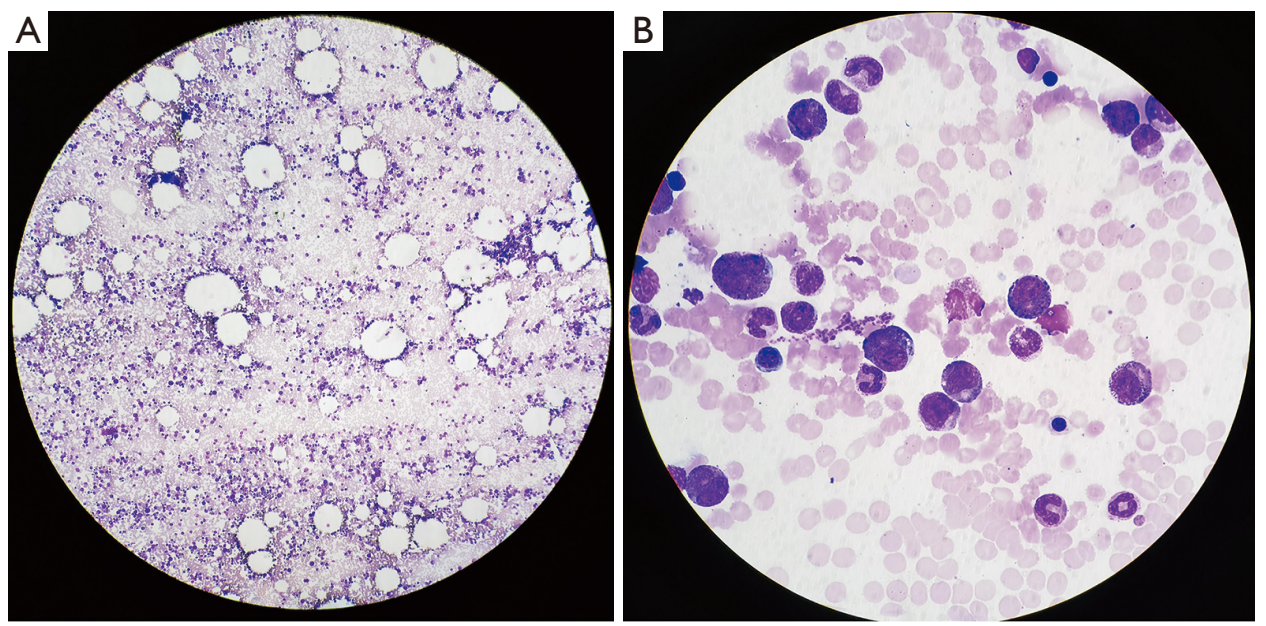

Figure 1 Bone marrow cytomorphology showing elevated eosinophils at different stages [Wright and Giemsa staining, (A) $\times 100$ and $($ B) $\times 1,000]$.
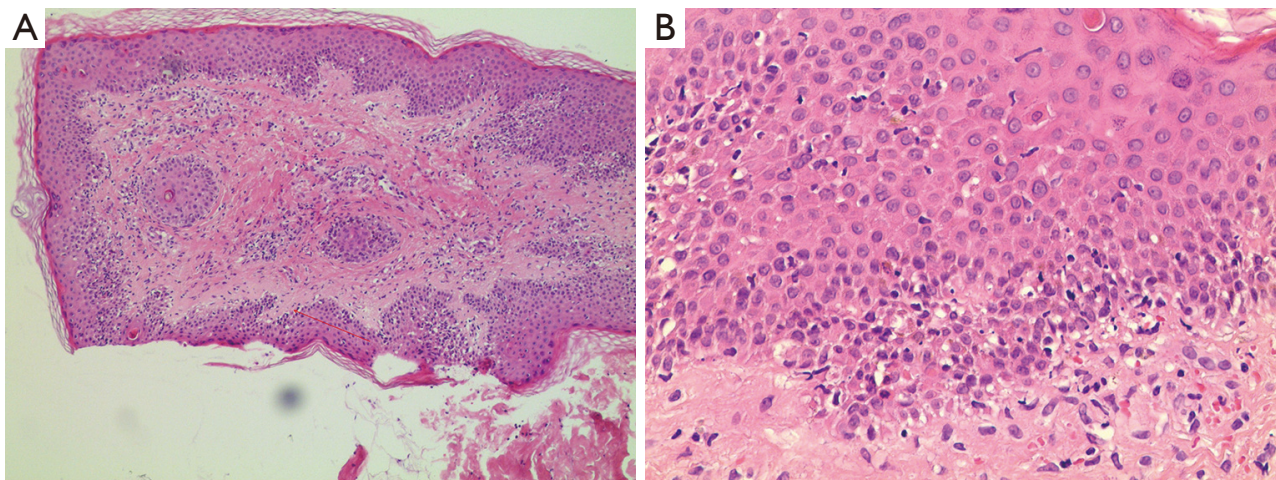

Figure 2 Skin biopsy showing tissue eosinophilia [hematoxylin and eosin staining, $(\mathrm{A}) \times 100$ and $(\mathrm{B}) \times 400$ ].
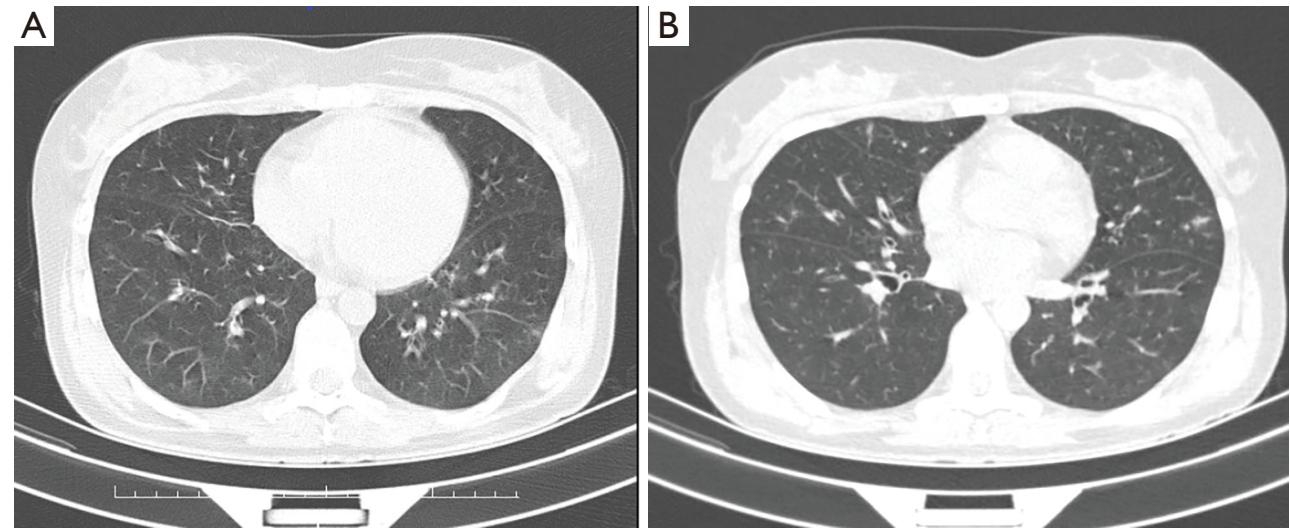

Figure 3 Two different levels of chest computed tomography scanning on admission for obvious diminution of small multiple small patchy and high-density nodules. 
reports showing the occurrence of vulvar granuloma, neuropathic ulcer, and corneal melt in EGPA (21-23).

In adult patients, additional respiratory manifestations are also very common. A study involving 62 people showed that peripheral neuropathy was noted in $55 \%$ and cardiac manifestations in $41 \%$ of cases. About 54\% (38/71) were ANCA-positive, with a perinuclear-labeling pattern and/or anti-MPO specificity. The central nervous system (CNS) was involved in $86 \%$ (76 cases), $52 \%$ (46 cases) had ischemic cerebrovascular lesions, $24 \%$ (21 cases) had intracerebral hemorrhage and/or subarachnoid hemorrhage, $33 \%$ (28 cases) had loss of visual acuity (15 with optic neuritis, 9 with central retinal artery occlusion, and 4 with cortical blindness), and $21 \%$ (18 cases) had cranial nerve palsies, with 25 patients having more than one clinical CNS manifestation (24).

Asthma is one of the respiratory symptoms of EGPA. Severe/uncontrolled asthma was observed in $42.7 \%$ of patients at diagnosis (25). There are several types of asthma: allergic asthma mediated by $\mathrm{IgE}$; nonallergic asthma often triggered by viral upper respiratory tract infections or no apparent cause; occupational asthma; aspirin-exacerbated respiratory disease; potentially fatal, exercise-induced asthma; and cough variant asthma. The latter type of asthma is the differential diagnosis of chronic cough. Our case was also a patient with cough variant asthma. Patients with cough variant asthma usually have a nonproductive cough, which only responds to treatment for asthma, but not to treatment with antibiotics, expectorants, mucolytics, antitussives, or beta-adrenergic agonists, and not to treatments for acid reflux and rhinosinusitis (26).

ANCA is one of kind of anti-neutrophil cytoplasmic antibodies, which is negative in most EGPA patients (15). In all, $40-70 \%$ of cases are ANCA negative. ANCA positive cases are usually accompanied by elevated eosinophils, which might mediate organ damage (27). Our patient was ANCA negative and had high levels of eosinophils in the bone marrow and peripheral blood accompanying her renal, heart, skin, nasal, and lung injuries. The possible mechanism of organ injury is eosinophil-associated vascular occlusion leading to ischemia and eosinophil-associated tissue damage (28).

The exact pathogenesis of EGPA is not fully understood but probably results from the mutual effects of $T$ and $B$ cells besides eosinophils (29). The present case showed a higher percentage of $\mathrm{T}$ cells, $\mathrm{CD}^{+}{ }^{+} \mathrm{T}$ cells, and $\mathrm{CD} 4^{+} \mathrm{T} /$ $\mathrm{CD}^{+} \mathrm{T}$ ratio; a lower percentage of $\mathrm{CD} 8^{+} \mathrm{T}$ cells, $\mathrm{B}$ cells, NK cells, and NKT; and a lower count of $\mathrm{CD} 8^{+} \mathrm{T}$ cells, B cells, NK cells, and NKT cells. Her Treg were within the reference range. These results suggest that this patient has higher cellular immunity, lower humoral immunity, and lower natural killer ability. Among cytokines produced by various immune cells, proinflammatoryIL- $6, \mathrm{IFN}-\gamma$ and TNF- $\alpha$ and anti-inflammatory IL-10 were higher while the others, such as proinflammatory IL-2 and IL-17A and antiinflammatory IL-4, were in the reference range. Serum C1q and $\mathrm{C} 3$ level were lower, which might have resulted from immune exhaustion of a high autoimmune response. All of the above suggests that both the imbalance of the immune system and the inflammatory response play an important role in EGPA pathogenesis. Another proof of this is that the recently developed monoclonal antibodies targeting $B$ cells and eosinophilopoietic cytokines such as IL-5, which is the major driver of eosinophilic inflammation and related high disease activity in EGPA, are emerging as valid alternatives to conventional immunosuppressive therapies $(29,30)$.

The present case revealed positive anti-HSV type $1+2$ IgG. HSV may cause tissue necrosis in EGPA. Shintaku et al. found that a 59-year-old woman with EGPA had HSV type 1 infection. Also, disseminated eosinophils and HSV were detected in her pancreatic tissue (31). We also found that this patient had positive anti-RV IgG. Whether RV plays role in EGPA has not been reported in the available literature. It is disappointing that we did not detect HSV and RV in her tissue.

The genetic basis of EGPA may contribute to EGPA. A previous study found that genes were mutated in four affected siblings suggesting genetic involvement in susceptibility to EGPA (32). This study found three EGPA cases in four members of a Saudi family affected by asthma. Another report from Japan relates to a sister and brother with EGPA (33). The HLA-DRB1 (34), HLA-DRB4 (35), and IL-10genes have been reported to play a role in EGPA pathogenesis (36).

Here we reported an EGPA case with a rare type of cough variant asthma. High-dose corticosteroids and immunomodulatory therapy were effective for EGPA. We highlighted cough variant asthma, which is easy to overlook as an initial presenting symptom of EGPA. The presence of eosinophilia and dry cough provided an opportunity for early diagnosis and treatment to reduce the risk of further disease progression and morbidity. More data are needed in relation to EGPA.

\section{Acknowledgments}

Funding: Key Research and Development Projects of Hebei Province (No. 1827772727D); Natural Science Foundation 
of Hebei Province (H202120603).

\section{Footnote}

Reporting Checklist: The authors have completed the CARE reporting checklist. Available at https://dx.doi. org/10.21037/apm-21-2236

Conflicts of Interest: All authors have completed the ICMJE uniform disclosure form (available at https://dx.doi. org/10.21037/apm-21-2236). The authors have no conflicts of interest to declare.

Ethical Statement: The authors are accountable for all aspects of the work in ensuring that questions related to the accuracy or integrity of any part of the work are appropriately investigated and resolved. All procedures performed in studies involving human participants were in accordance with the ethical standards of the institutional and/or national research committee(s) and with the Helsinki Declaration (as revised in 2013). Written informed consent was obtained from the patient for publication of this case report and accompanying images. A copy of the written consent is available for review by the editorial office of this journal.

Open Access Statement: This is an Open Access article distributed in accordance with the Creative Commons Attribution-NonCommercial-NoDerivs 4.0 International License (CC BY-NC-ND 4.0), which permits the noncommercial replication and distribution of the article with the strict proviso that no changes or edits are made and the original work is properly cited (including links to both the formal publication through the relevant DOI and the license). See: https://creativecommons.org/licenses/by-nc-nd/4.0/.

\section{References}

1. Jennette JC, Falk RJ, Bacon PA, et al. 2012 revised International Chapel Hill Consensus Conference Nomenclature of Vasculitides. Arthritis Rheum 2013;65:1-11.

2. Sada KE, Amano K, Uehara R, et al. A nationwide survey on the epidemiology and clinical features of eosinophilic granulomatosis with polyangiitis (Churg-Strauss) in Japan. Mod Rheumatol 2014;24:640-4.

3. Guillevin L, Visser H, Noel LH, et al. Antineutrophil cytoplasm antibodies in systemic polyarteritis nodosa with and without hepatitis B virus infection and Churg-Strauss syndrome--62 patients. J Rheumatol 1993;20:1345-9.

4. Sinico RA, Di Toma L, Maggiore U, et al. Renal involvement in Churg-Strauss syndrome. Am J Kidney Dis 2006;47:770-9.

5. Nguyen Y, Guillevin L. Eosinophilic Granulomatosis with Polyangiitis (Churg-Strauss). Semin Respir Crit Care Med 2018;39:471-81.

6. Jennette JC, Falk RJ, Andrassy K, et al. Nomenclature of systemic vasculitides. Proposal of an international consensus conference. Arthritis Rheum 1994;37:187-92.

7. Bridges C, Shenk MER, Martin K, et al. Cutaneous manifestations of childhood Eosinophilic Granulomatosis with Polyangiitis (cEGPA): A case-based review. Pediatr Dermatol 2020;37:604-12.

8. Zhang MY, Lin JT. Eosinophilic granulomatosis with polyangiitis: 30 cases report. Zhonghua Yi Xue Za Zhi 2019;99:1216-20.

9. Itawaki A, Okada M, Kawashima K, et al. Eosinophilic Granulomatosis with Polyangiitis Initially Diagnosed as Eosinophilic Gastroenteritis. Intern Med 2020;59:1029-33.

10. Ekeigwe NL, Adelowo O, Anaba EL, et al. Eosinophilic granulomatosis with polyangiitis in a Nigerian woman. BMJ Case Rep 2019;12:228901.

11. Daskalakis GJ, Pergialiotis VP, Theodora MK, et al. Pregnancy in a patient with eosinophilic granulomatosis with polyangiitis. J Obstet Gynaecol 2019;39:558-9.

12. Saito $Y$, Watanabe T, Hattori $T$, et al. Intracranial vasculitis in eosinophilic granulomatosis with polyangiitis. Rheumatology (Oxford) 2018;57:2253.

13. Kalinova D, Kukushev G, Kolarov Z, et al. Severe mononeuritis multiplex in a patient with eosinophilic granulomatosis with polyangiitis. Reumatologia 2019;57:288-91.

14. Pacholczak R, Bazan-Socha S, Iwaniec T, et al. Endothelial dysfunction in patients with eosinophilic granulomatosis with polyangiitis. Clin Rheumatol 2019;38:417-24.

15. Eleftheriou D, Gale H, Pilkington C, et al. Eosinophilic granulomatosis with polyangiitis in childhood: retrospective experience from a tertiary referral centre in the UK. Rheumatology (Oxford) 2016;55:1263-72.

16. Bosco L, Peroni A, Schena D, et al. Cutaneous manifestations of Churg-Strauss syndrome: report of two cases and review of the literature. Clin Rheumatol 2011;30:573-80.

17. Liu X, Wang L, Zhou K, et al. A delayed diagnosis of eosinophilic granulomatosis with polyangiitis complicated with extensive artery occlusion of lower extremities 
in children: case report and literature review. Pediatr Rheumatol Online J 2019;17:26.

18. Zwerina J, Eger G, Englbrecht M, et al. Churg-Strauss syndrome in childhood: a systematic literature review and clinical comparison with adult patients. Semin Arthritis Rheum 2009;39:108-15.

19. Gendelman S, Zeft A, Spalding SJ. Childhood-onset eosinophilic granulomatosis with polyangiitis (formerly Churg-Strauss syndrome): a contemporary single-center cohort. J Rheumatol 2013;40:929-35.

20. Fina A, Dubus JC, Tran A, et al. Eosinophilic granulomatosis with polyangiitis in children: Data from the French RespiRare ${ }^{\circledR}$ cohort. Pediatr Pulmonol 2018;53:1640-50.

21. Swain CA, Sherry TR, Tyson N. Childhood-Onset Eosinophilic Granulomatosis with Polyangiitis with a Vulvar Granuloma: A Case Report and Review of the Literature. J Pediatr Adolesc Gynecol 2019;32:425-8.

22. Selladurai $P$, Thinesskaran $P$, Selvaratnam $G$, et al. Neuropathic ulcer: rare manifestation of Eosinophilic granulomatosis with polyangiitis. Sri Lanka J Surg 2018;36:42-3.

23. Fennelly E, Greenan E, Murphy CC. Corneal melt secondary to eosinophilic granulomatosis with polyangiitis. BMJ Case Rep 2019;12:229859.

24. André R, Cottin V, Saraux JL, et al. Central nervous system involvement in eosinophilic granulomatosis with polyangiitis (Churg-Strauss): Report of 26 patients and review of the literature. Autoimmun Rev 2017;16:963-9.

25. Berti A, Cornec D, Casal Moura M, et al. Eosinophilic Granulomatosis With Polyangiitis: Clinical Predictors of Long-term Asthma Severity. Chest 2020;157:1086-99.

26. Padem N, Saltoun C. Classification of asthma. Allergy Asthma Proc 2019;40:385-8.

27. Gioffredi A, Maritati F, Oliva E, et al. Eosinophilic granulomatosis with polyangiitis: an overview. Front

Cite this article as: $\mathrm{Li} \mathrm{Y,} \mathrm{Chen} \mathrm{Z,} \mathrm{Zhu} \mathrm{S,} \mathrm{Bai} \mathrm{F,} \mathrm{Liu} \mathrm{Y,} \mathrm{Gao} \mathrm{L,}$ Li X, Geng Y, Zhang G. Negative anti-neutrophil cytoplasmic antibodies and eosinophilic granulomatosis with polyangiitis accompanied by cough variant asthma: a case report. Ann Palliat Med 2021;10(10):11209-11215. doi: 10.21037/apm-21-2236
Immunol 2014;5:549.

28. Nishi R, Koike H, Ohyama K, et al. Differential clinicopathologic features of EGPA-associated neuropathy with and without ANCA. Neurology 2020;94:e1726-37.

29. Kataoka H, Tomita T, Kondo M, et al. Presence of purpura is related to active inflammation in association with IL-5 in eosinophilic granulomatosis with polyangiitis. Rheumatol Int 2021;41:449-54.

30. Trivioli G, Terrier B, Vaglio A. Eosinophilic granulomatosis with polyangiitis: understanding the disease and its management. Rheumatology (Oxford) 2020;59:iii84-94.

31. Shintaku M, Umehara Y, Iwaisako K, et al. Herpes simplex pancreatitis. Arch Pathol Lab Med 2003;127:231-4.

32. Arfaj A, Anazi MA, Khalil N, et al. Familial eosinophilic granulomatosis with polyangiitis. Open J Rheumat Autoimmune Dis 2017;7:137-46.

33. Ueki Y, Oshikata C, Asai Y, et al. Familial Eosinophilic Granulomatosis with Polyangiitis in a Sister and Brother. Intern Med 2020;59:991-5.

34. Wieczorek S, Hellmich B, Gross WL, et al. Associations of Churg-Strauss syndrome with the HLA-DRB1 locus, and relationship to the genetics of antineutrophil cytoplasmic antibody-associated vasculitides: comment on the article by Vaglio et al. Arthritis Rheum 2008;58:329-30.

35. Vaglio A, Martorana D, Maggiore U, et al. HLA-DRB4 as a genetic risk factor for Churg-Strauss syndrome. Arthritis Rheum 2007;56:3159-66.

36. Wieczorek S, Hellmich B, Arning L, et al. Functionally relevant variations of the interleukin-10 gene associated with antineutrophil cytoplasmic antibody-negative ChurgStrauss syndrome, but not with Wegener's granulomatosis. Arthritis Rheum 2008;58:1839-48.

(English Language Editor: J. Meiser) 